\title{
DRAMATIC REDUCTION OF POSTNATAL GROWTH RESTRICTION AFTER OPTIMIZING NUTRITION IN VERY LOW BIRTH WEIGHT INFANTS
}

\author{
T. Senterre, J. Rigo \\ University of Liège, Liège, Belgium
}

Objective: The aim of this study was to evaluate postnatal growth up discharge in VLBW infants after optimizing nutritional support based on early "aggressive" nutrition and recent recommendations.

Methods: A prospective non randomized, consecutive and observational study in $<1250 \mathrm{~g}$ infants during a 2 years period.

Results: 102 infants were included (BW= $1005 \pm 157 \mathrm{~g}, \mathrm{GA}=28.5 \pm 1.9$ weeks). First day nutritional intake was $38 \pm 6 \mathrm{kcal} / \mathrm{kg}^{*}$ day with $2.4 \pm 0.3 \mathrm{~g} / \mathrm{kg} *$ day of protein. Mean intake during the first week of life was 80 $\pm 14 \mathrm{kcal} / \mathrm{kg} *$ day with $3.2 \pm 0.5 \mathrm{~g} / \mathrm{kg} *$ day of protein and $122 \pm 10 \mathrm{kcal} / \mathrm{kg} *$ day and $3.7 \pm 0.2 \mathrm{~g} / \mathrm{kg} *$ day of protein during all the study period.

Postnatal weight loss was limited to the first 3 days of life and BW was regained after 7 days in average. Catch-up occurred after the second week in all groups of VLBW infants. Small for gestational age (SGA) infants demonstrated an earlier and higher weight gain allowing the reduction of SGA infants at discharge. The same proportion of infants were SGA at discharge and at birth $(20 \%, \mathrm{p}=0.74)$.

Conclusion: This study confirmed that the first week of life is a critical period to promote growth and that early aggressive nutrition is essential. Postnatal weight loss may be limited and subsequent growth may be optimized with a dramatic reduction of postnatal growth restriction. 